\title{
STUDENT'S ABILITY IN WRITING ENGLISH EXPOSITION TEXT: DESCRIPTIVE STUDY AT THE SECOND GRADE OF SENIOR HIGH SCHOOL OF HANGTUAH 3 MATARAM IN ACADEMIC YEAR 2015/2016 \\ ${ }^{(1)}$ Muslimin ${ }^{(2)}$ Nurul Ichsaniati
}

${ }^{(1)}$ Lecturer of English Department Muhammadiyah University of Mataram

${ }^{(2)}$ Students of English Department Muhammadiyah University of Mataram

\begin{abstract}
The population of this research was the second grade students of SMA 3 Hangtuah Mataram in academic year 2015/2016 which consist of 2 classes. It means that all of population was 30 students and this population makes sample 30 students'. The thesis aimed to find out the student's ability in writing English exposition text: descriptive study at the second grade of senior high school of Hangtuah 3 Mataram in academic year 2015/2016. The researcher took 30 students of the second years students of Hangtuah 3 Mataram to be respondents/sample, the population only two classes consists of 30 students. In collecting data, the researcher used writing test. The students were asked to make paragraph in exposition text. The data analysis, the students score were found that student's ability in writing English exposition text as good in 2 class ( 30 students), in this case, in class 2 there are no students got excellent , 20 students got good level (67\%), 8 students got very good criteria (26\%), and 2 students got fairly good criteria (7\%). Based on the result above it can be conclude that the students ability in writing English exposition text 20 students "good" criteria or $67 \%$.
\end{abstract}

Key word: writing, exposition text.

INTRODUCTION

This section introduces some basic information of the study, which covers: the background of the study, research question, and the objective of the study, significance of the study, scope of study and the definition of key terms.

\subsection{Background of the study}

There are two kinds of text exposition. The analytical exposition text and hortatory exposition text, analytical exposition text goal is to expose and influenced the readers the readers that there is problem that needs attention. Communicative purposes of analytical exposition are to convince the reader that the topic presented is an important topic to discuss or get attention by providing arguments or opinions that support the main idea or topic. Analytical Exposition text is a piece of text that presents one side of an issue. If you have ever tried to persuade someone to believe something or if you have argued with someone, then you have used the analytical exposition text type. The purpose of an analytical exposition text is to persuade the reader or listener by resenting one side of an argument. Analytical exposition text usually has three sections. The first section introduces the author's point of view and can preview arguments that may follow in the text. Next comes a series of arguments that that aim to convince the audience. The final section is a conclusion that sums up 
the arguments and reinforces the author's point of view (Anderson \& Anderson, 1998: 22).

In the first years of senior high school, the basic competency that should be achieved in the writing English subject is the students have ability to develop and procedure written simple functional text in the recount text, narrative text, news items, procedure, descriptive and exposition text.

Sometimes the teacher asks the students to write or to make paragraph individually. The problems faced in the class are sometimes the students have difficulties to build and develop their ideas, choose the right dictions, and the use of grammar. Writing individually does not work optimally increasing the students writing ability.

The researcher has done some observation during teaching practice at of Hangtuah 3 Mataram in Academic Year 2015/2016, The similar problem had been investigated by some researchers, first, Dewi Wulandari (2012). She investigated about "The study of students' ability in writing analytical exposition text. The second study had been investigated by Rina Mayasari (2012). She investigated about "The Use of Group Investigation to Improve Students' Ability in Writing Skill on Analytical Exposition Text. In this study, the researcher is interested to use exposition text in order to analyze student's ability in writing skill. Related to the background of the study and the research problem above, this study is conduct to know the students' ability in writing exposition text at the second grade students of Senior High School of Hangtuah 3 Mataram in Academic Year 2015/2016.

\section{REVIEW OF RELATED LITERATURE}

This section discuss the, Definition of Writing, The Nature of Writing, Principle of Teaching Writing, Types of writing performances, Writing process, written text types, Exposition Text, Previous Study.

\subsection{Written text types}

\section{Procedure}

A procedure is a piece of text that tells the reader or listener how to do something. Its purpose is to provide instructions for making something, doing something or getting somewhere.

\subsection{Analytical Exposition Text}

Analytical Exposition text is a piece of text that presents one side of an issue. If you have ever tried to persuade someone to believe something or if you have argued with someone, then you have used the exposition text type. The purpose of an exposition text is to persuade the reader or listener by resenting one side of an argument. (Anderson \& Anderson, 1998: 22)

Analytical exposition text is used to argue a point of view of to persuade the audiences to do something. Usually, the written exposition has three main parts, shown in this scaffold:

1. An introductory statement 
a. The author's point of view is called the thesis of the argument and this is given in the introduction.

b. The introduction can include a preview of the arguments that will follow in the next section of the next.

c. A question or emotional statement can be used to get audience attention

2. A series of arguments to convinces the audience

a. A new paragraph is used for each new argument.

b. Each new paragraph begins with topic sentences that introduce a new argument.

c. After the topic sentence comes details that support the argument.

d. Emotive words are used to persuade the audience into believing the author.

3. A conclusion summing up the arguments

a. The author restates his/her thesis (point of view)

b. A summary of what has been stated in the section above may be including here.

\subsubsection{Constructing an exposition text}

The steps for constructing an exposition are:

a. An introductory statement that gives the author's point of view and previews the argument that will follow-in some txt, the opening statement may be 'attention grabbing'.

b. A series of argument that aims to convince the audience, picture might also be used to help persuade to audience.

c. A conclusion that sums up the arguments and reinforces the author's point of view.

\subsubsection{Language features of an exposition}

The language features usually found in an exposition text are:

a. The use of words that show the author's attitude (modality).

b. The use of words that express feelings (emotive words).

c. The use of words to link cause and effect.

\subsection{Analytical Exposition Text}

An analytical exposition is a type of spoken or written text that is intended to persuade the listeners or readers that something is the case. It also collaborate that writer's idea about the phenomenon surrounding. The purpose of an analytical exposition text is to persuade the readers or listener by presenting one side of an argument. To make the persuasion stronger, the speaker or writer gives some arguments as the fundamental reasons why something is the case. This type of text can be found in scientific books, journals, magazines, newspaper articles, academic speech or lectures, research report etc. Analytical expositions are popular among science, academic community and educated people.Analytical exposition text have 3 components, they are: constructing an exposition, language feature an exposition and generic structure. the (Anderson \& Anderson, 1998: 124)

First is constructing an Analytical Exposition. In constructing an analytical exposition text, there are three basic steps, the first step is called as an introductory 
statement that gives the author's point of view and previews the arguments that will follow-in some texts, the opening statements may be attention grabbing. The second step is by constructing a series of arguments that aim to convince the audience, pictures might also be used to help persuade the audience. The last one is by constructing a conclusion that sums up the arguments and reinforces the author's point of view.

After constructing an analytical exposition text, then language features of an Analytical Exposition text. The language features of Analytical Exposition consist of three kinds. First, the use of words that shows the author's attitude, or we usually call it as modality. The second one is the use of words to express felling or we usually call it as emotive words. The last one is the use of words to link cause and effect.

The next step after we know about language feature of an analytical exposition text is the generic structure of analytical exposition. The generic structure of analytical exposition consists of three main parts: thesis, arguments and reiteration ( Linda Garot \& Peter Wignal, 1994:197 ). The first part is called as thesis. Thesis is used for introducing topic and indicates the writer's position. Besides, thesis is also used as the outline of the main argument, to be presented.

The second part is called as argument. The use of arguments is to restate main argument outlined in preview. It consists of the elaboration, development, and support to each point of argument.

The last one is reiteration. It is usually used for restating the writer's position and to conclude the whole argument.

Some dominant features that usually used when writing analytical exposition text, it is usually focused on generic human and non-human participants. It means that the subject of the general things can be human and non-human (Linda Garot \& Peter Wignal, 1994:198).

Another characteristic is the use of simple present tense. This tense is used because it shows the events that exist now, in the past and in the future. There are also the uses of relational processes to express the cause and effect event. The use of internal conjunction is to stage the argument and to show the series of argument that contain more than one argument. Last but not least is the reasoning through causal conjunction to show the conclusion of the whole arguments in the text ( Linda Garot \& Peter Wignal, 1994:198).

\section{RESEARCH METHODOLOGY}

This section discusses about the research design, population and sample, instrument, technique of data collection. Then the last is about technique of data analysis.

\subsection{Research Design}

The method of this research was descriptive qualitative method. It is the general method, but the specific method which relates to the data collection procedure is testing technique. This research is not intended to examine the certain hypothesis yet it describes the variable as far as possible (Arikunto, 2003:310). By considering this definition the researcher to know the students ability in writing exposition text. 


\subsection{Population and sample}

\subsubsection{Population}

The population means generalization region consist of object/subject that have certain qualities and characteristic are determined by investigators to be studied and then draws conclusions (Sugiyono, 2010:80). The population of this research was the second grade students of SMA 3 Hangtuah Mataram in academic year 2015/2016 which consist 30 students. As the population is lower than one hundred, the writer used all of them as the sample of the study (Arikunto, 1991:10).

\section{Sample}

Sample is a small part of population to the investigated. Arikunto (1991:129) defines that the sample is the amount of people less than population and small group that is observed. By the considering the definitions above the researcher take the 30 students as the sample.

\subsection{The instrument}

The instrument belong an important element in a research because it would be used to collect data to support investigation. Instrument is the methods which can be used to gather evidence in action research (Harmer, 2001; 346). Test was one of instruments which can be used to collect qualitative data.

Based on the Arikunto $(2010 ; 193)$ there are some kinds of the instrument, they are test, questionnaires, interview, observation, rating scale, and documentation. In this research the researcher used test as the instrument, the test was exposition text. The researcher asked the students to write an exposition text.

\subsection{Technique of Data Collection}

The data collected from the students' written test. The data collected from students' ability in writing exposition text in form of written test. An appropriate technique must be applied to gather the data need. This research applies measurement technique which intended to measure the students' ability in writing exposition text in written test. In this research the researcher write provided a form consist of the teacher's activities in class especially for students' ability in writing exposition text and, the researcher gave students test to write exposition text. In order, to make the students easy to write exposition text, the researchers gave some topic related with exposition text and ask the student choose the topic based on their need.

\subsection{Method Of Analysis Data}

The analysis the data, the researcher takes qualitative. The researcher used the following score system:

1. Scoring the students right make paragraph.

$$
\mathrm{X}=\frac{\sum S}{N}
$$

Where

$$
\begin{aligned}
\sum S & =\text { The students score } \\
\mathrm{N} & =\text { Total of students } \\
\mathrm{X} & =\text { The mean score of the students }
\end{aligned}
$$

(Arikunto, 2010:321) 
2. Classifying the score of the student

The result of students score are converted in to score scale in the table 3 to determine the student ability in writing English exposition text.

$\mathrm{P}=\frac{F}{N} \times 100 \%$

$$
\begin{aligned}
& \mathrm{P}=\text { Percentage } \\
& \mathrm{F}=\text { Frequency of the students' ability } \\
& \mathrm{N}=\text { The number of students }
\end{aligned}
$$

(Sudijono, 1997:40-41)

\section{FINDING AND DISCUSION}

The was problem that have been stated in statement of problem. Problem was "To know the student's ability in writing exposition text at the second grade students of Senior High School of Hangtuah 3 Mataram in Academic Year 2015/2016?". Therefore the researcher described the answer of the problem. However, before answering the problem, the researcher divided problem namely the student "ability in writing English exposition text.

\subsection{Data Interpretation}

In this chapter the researcher wants the show statistical of the data obtained. The analysis leads the discussion towards the finding of the investigation. Before the researcher comes to conclusion, discussion is continued to the analysis to interpretation of the data.

$\mathrm{X}=\frac{\sum S}{N}$

Notation

$\sum S=1890$

$\mathrm{N}=30$

Calculation

$X=\frac{\sum S}{N}$

$M=\frac{1890}{30}$

$=63,1$

Based on the means score of total result of class 2 the level classifying score of class 2 was good $(63,1)$. So, class 2 is good criteria for write analytical exposition text.

a. The percentages of students qualifications

Based on the finding above the researcher got the percentages of the students' qualification by using formula and below.

Table 4.3 the frequency and percentages of test in class 2 IPA \& 2 IPS

\begin{tabular}{|l|l|l|l|}
\hline Score & Classification & Frequency & Percentage \\
\hline
\end{tabular}




\begin{tabular}{|l|l|l|l|}
\hline $16-32$ & Poor & 0 & $\%$ \\
\hline $33-52$ & Fairly Good & 2 & $7 \%$ \\
\hline $53-72$ & Good & 20 & $67 \%$ \\
\hline $73-83$ & Very Good & 8 & $26 \%$ \\
\hline $84-100$ & Excellent & 0 & 0 \\
\hline
\end{tabular}

Categories were very good, good, and fairly good. After scored of students ability in writing English exposition text were classified, the researcher found 8 students' got very good, it meant that $26 \%$ of them got good score, 20 students' got good score, it meant that $67 \%$ of them who got good score, and 2 students' got fairly good, it meant that $7 \%$ of them got good score.

\section{Discussion}

The discussion ideals with the analysis of the students' ability in writing. The results of the analyzing students' scores were found that students' ability in writing English exposition text were categorized as good because the result $67 \%$ or 20 students. In addition, there were 8 students who were classified as very good score because their score was higher than 79 from 30 students. It showed that those $26 \%$ students have a good skill in writing exposition text including mastery in grammar, vocabulary and crating an exposition text. In addition, there were 20 students, who were classified as the good score because their score was higher than 65 from 30 students'. It showed that those $67 \%$ students have a good skill in writing exposition text including mastery in grammar, vocabulary and crating an exposition text. The last there were 2 students, who were classified as the fairly good score because their score was higher than 52 from 30 students'. It showed that those 7\% students have a fairly good skill in writing exposition text including mastery in grammar, vocabulary and crating an exposition text.

\section{CONCLUSION AND SUGGESTION}

\subsection{Conclusion}

Based on the discussion on the previous chapter, this study can be concluding as followed by qualitative description of the student ability in writing exposition text. It was also found the solution as the result of analysis.

Base on the study, it can be conclude the students' have ability in writing English exposition text that was found that students ability in writing English exposition text were categorized as good because the result it showed that 20 or $67 \%$ students' got score good score, 8 or $26 \%$ got very good, and 2 or $7 \%$ students got fairly good score. Based on the result above it can be conclude that the student's ability in wring English exposition text 20 students got good score or $67 \%$

\subsection{Suggestion}

Based on the discussion and conclusion, the researcher can suggest as follow. For the teacher 
a. The teachers of SMA Hangtuah 3 Mataram give more motivation to the students in writing English exposition text.

b. The teacher of SMA Hangtuah 3 Mataram should teach English grammar intensively especially in writing exposition text and give much practice to the students.

For the students

a. The first years students of senior high school especially of SMA Hangtuah 3 Mataram have to learn and practice as much as possible about exposition text.

b. The student should be to learn in how to make paragraph exposition text.

\section{BIBLIOGRAPHY}

Anderson, Mark and Anderson, Kathy. 1998. Text Type in English. Australia : Macmillan Education Australia

Arikunto, Suharsimi. 2010. Prosedur Penelitian; suatu Pendekatan Praktik. Jakarta: Rineka Cipta

Arikunto, Suharsimi. 2006. Metodologi Penelitian. Jakarta: Rineka Cipta.

Arikunto, Suharsimi. 1991. Prosedur Penelitian Sebuah Pendekatan Praktek. Jakarta: Rineka Cipta.

Brown, H.D. 2001. Teaching by Principles: Approach to Language Pedagogy. $\left(2^{\text {nd }}\right.$ eds) San Francisco: Addison Wesley Longman Inc.

Brown, H.D. 2004. Electric Journal of Foreign Language Teaching, Harlow: Lonman.

Garot, linda and Wignel, Peter, Making Sense of Functional Grammar, (Australia: antipodean Educational Enterprises, 1994)

Harmer, Jeremy. 2001. How To Teach Writing,Harlow : Longman

Harmer, Jeremy. 2004. How To Teach Writing,Harlow : Longman

Harsyah, et. al. 2009. Teaching writing. Jakarta : Bermutu

Heaton, J.B. 1975. Writing English Language Test, Singapure : Longman Group Ltd.

Hornby, 1973. Oxford Advance Learner's Dictionary of Current English, London: Oxford University Press

Hughes, Arthur. 2003. Teasting for Language Teacher. London: Cambridge University Press.

Mayasari, Rina. 2012. The used of group investigation to improve students ability in writing skill on analitycal exposition text. Semarang

Nunan, David. 2003. Practical English Language Teaching. New York. The MograwHill.

Sugiyono, 2010. Metode Penelitian Kuantitatif kualitatif dan R\&D. Alfabeta : Bandung

Sundem, Garth.M.M. 2006. Improving Students' Writing Skills. USA:Shell Education.

Wulandari, dewi. 2011. The ability of writing analitycal exposition text of the eleventh grade students of SMAN 2 Kudus in academic year 2011/2012. University maria kudu 